\title{
A multimodalidade na literatura infantil e a formação de professores leitores
}

\author{
Multimodality in infant literature books and \\ the education of reader teachers
}

Celia Abicalil Belmiro*

Universidade Federal de Minas Gerais

\begin{abstract}
RESUMO: Este trabalho apresenta uma parte dos resultados de pesquisa de doutorado sobre relaçôes entre imagens e textos verbais em livros de literatura infantil, e suas contribuições para a formação docente. São sinalizados diferentes recursos discursivos encontrados em imagens e textos em livros de literatura infantil para a construção das dimensões narrativa e descritiva. O conceito bakhtiniano de estilo estrutura e unifica os enunciados produzidos pelo enunciador e indica o resultado de uma visão de mundo. Nas obras analisadas, a relação imagem e texto verbal apresenta dois recursos fundamentais: a enunciação, que introduz a força do narrador na orientação de leitura, e a intertextualidade, como expediente para atualização do enredo. Essa metodologia recupera experiências de leitura dos professores e indica a importância dos aspectos da multimodalidade para a formação da competência leitora do professor.
\end{abstract}

PALAVRAS-CHAVE: Imagem, texto verbal, literatura, formação docente

ABSTRACT: This paper presents a part of the results of a Doctorate research on the relations between images and verbal texts in infant literature books and their contribution to the education of teachers. Different discursive resources were found in images and texts in infant literature books towards the construction of the narrative and descriptive dimensions. Bakhtin's concept of style helps providing structure and unity to the enunciated production of the enunciator and indicates the result of a world vision. In the works here analyzed, the relation between image and verbal text presents two fundamental resources: the enunciation, as the power of the narrator in guiding the reading, and intertextuality, as a device to update the plot. This methodology allows the recovering of teachers' reading experiences and indicates the importance of multimodality aspects in the construction of teachers' reading ability.

KEYWORDS: Image, verbal text, literature, teachers'education.

*celiab@terra.com.br.

Professora da Faculdade de Educação/UFMG e pesquisadora do CEALE - Centro de Alfabetização, Leitura e Escrita. 


\section{Introdução}

Este trabalho apresenta uma parte dos resultados de pesquisa de doutorado ${ }^{1}$ sobre relações entre imagens e textos verbais em livros de literatura infantil e tem a finalidade de trazer contribuiçōes para a formação docente. Filia-se à linha de pesquisa sobre letramento e alfabetização, destacando nos gêneros discursivos as relaçóes entre imagens e textos verbais, a partir de suas naturezas constitutivas. O propósito deste texto é indicar alguns recursos discursivos encontrados em imagens e textos em livros de literatura infantil que contribuam para a construção das dimensões narrativa e descritiva.

Preliminarmente, apresento algumas explicações sobre a escolha do material e o olhar para ele voltado, a fim de compreender o modo de abordagem da pesquisa, que é verificar as relações entre imagem e texto verbal atravessadas pelas categorias do visível e do legível.

As reflexões metodológicas baseiam-se em algumas práticas de trabalho que venho trilhando nos últimos anos: uma delas é o estudo específico sobre o objeto livro didático de língua portuguesa e as propostas de relação entre as imagens e os textos, sejam literários ou não; outro aspecto é o estudo de livros de literatura infantil, nos quais me concentro nas diferentes práticas de escrita visual e verbal; por fim, como se articulam novas formas de sociabilidades por essas escritas e as dificuldades de assimilação desses comportamentos pelas práticas escolares. Tanto individualmente quanto em âmbito geral, os estudos têm mostrado a importância da presença do professor mediador nas produções ditas escolares e as possibilidades de diálogo advindas da presença implícita do leitor literário mirim.

A escolha dos livros de literatura infantil deu preferência a um grupo de 29 obras, selecionadas por uma visada que possibilitasse compreender e discutir certas reduções na relação da imagem com o texto verbal, com a finalidade de facilitar a interpretação infantil. Foram assim divididos: 19 livros são parte integrante das obras do PNBE (2006 e 2008)² e 10 livros fazem parte do

\footnotetext{
${ }^{1}$ Tese de doutorado defendida na Faculdade de Educação da Universidade Federal Fluminense, sob orientação da Profa. Dra. Cecília Maria Aldigueri Goulart.

${ }^{2}$ Trata-se do Plano Nacional de Biblioteca Escolar, que avaliou e selecionou obras de literatura, no intuito de compor acervos para escolas públicas das séries finais do Ensino Fundamental - PNBE 2006 - e da Educação Infantil e escolas públicas que atendem as séries iniciais do Ensino Fundamental - PNBE 2008 -, ambos coordenados pelo Centro de Alfabetização, Leitura e Escrita (CEALE) da Faculdade de Educação da UFMG, em convênio com a Secretaria de Educação Básica do MEC.
} 
acervo do PROALE. ${ }^{3} \mathrm{O}$ interesse do estudo não se prende à construção de categorias que possam se tornar universais, mas ao desejo de dar entendimento a certas relações entre texto e imagem nesse suporte e nesse gênero. Os livros selecionados apresentam características importantes que permitem avançar nas interrogações apontadas já em textos anteriores; ${ }^{4}$ essas obras são publicações atuais (algumas da década de 1970), podendo indicar caminhos pelos quais autores e ilustradores optaram para que essas duas dimensões de linguagem pudessem (ou não) ser permeadas uma pela outra. Com isso, suponho que a discussão que trago no momento possa esclarecer o modo como a multiplicidade de relaçôes entre imagem e texto tem amparo: no respeito a diferentes processos de conhecimento que sejam permeados tanto pela linguagem visual quanto pela verbal; nas mudanças de valor outorgado a esses dois modos de expressão do homem; na assimilação de tecnologias como apoio para a divulgação de idéias e para a construção de novas modalidades expressivas; na ativação de processos cognitivos da visualidade até então não valorizados.

\section{Conceitos e textos abordados na pesquisa: o estilo, a enunciação, a interdiscursividade}

A partir do conceito bakhtiniano de estilo, estruturam-se e unificam-se os enunciados produzidos pelo enunciador e por meio do conjunto descritivo apreende-se um estilo de vida. Nas obras analisadas, a relação imagem e texto verbal apresenta dois recursos fundamentais para sua realização: o primeiro é a predominância da enunciação que introduz a força do narrador na orientação de leitura. O segundo é o da interdiscursividade: utilizado em algumas narrativas infantis como expediente para atualização do enredo. Esse recurso traz para os nossos dias o imaginário do conto de fadas tradicional, aproximando-o do imaginário das crianças do século 21 , que agregam experiências na área da tecnologia, da insegurança urbana, das transformações por que passa a estrutura familiar; tantas são as diferenças das crianças do mundo de Perrault, Andersen, entre outros. As categorias apresentadas são uma orientação metodológica de aproximar as obras em grandes eixos e serão mais bem detalhadas ao longo das análises, destacando-se as especificidades encontradas. Dessa forma, este texto

3 PROALE - Programa de Alfabetização e Leitura, vinculado à Faculdade de Educação/Universidade Federal Fluminense.

${ }^{4}$ Ver, para esse estudo, Belmiro (2000, 2003, 2004). 
pretende enfatizar a importância dos aspectos da multimodalidade para a formação da competência leitora do professor.

\section{$O$ aspecto do estilo}

O livro Vizinho, vizinha, de Roger Melo, com ilustraçōes do próprio autor, de Graça Lima e de Mariana Massarani, propõe uma leitura múltipla, aberta, pelo trabalho com imagens, palavras e imagem / palavra. São três ilustradores que assumem, cada um, os três protagonistas do livro e definem seus modos de ser através de cores, de traços, de volumes por meio de um estilo próprio, que é estruturado pela linguagem fundada socialmente, definida por Bakhtin por suas marcas ideológicas. Isso porque há tanto trabalho verbal quanto imagético e uma proposta de interação entre essas duas dimensões, de forma a construir um vasto campo de possibilidades de leitura. Uma dominante na proposta do livro é a complementaridade permanente entre a imagem e o texto em forma de legenda; muito do que dizem as imagens não tem paralelo no texto escrito, e vice-versa. Todavia, outra proposta igualmente relevante é o diálogo entre as imagens, como que demarcando, pela descrição constante, as personagens, seus modos de ser, seus atributos físicos e psicológicos, enfim, uma composição visual que ultrapassa a transcrição denotativa do texto verbal e amplia as conotações e implicaçõos assumidas pela plasticidade das imagens (FIG.1). Ex: "O vizinho coleciona discos da velha guarda”.

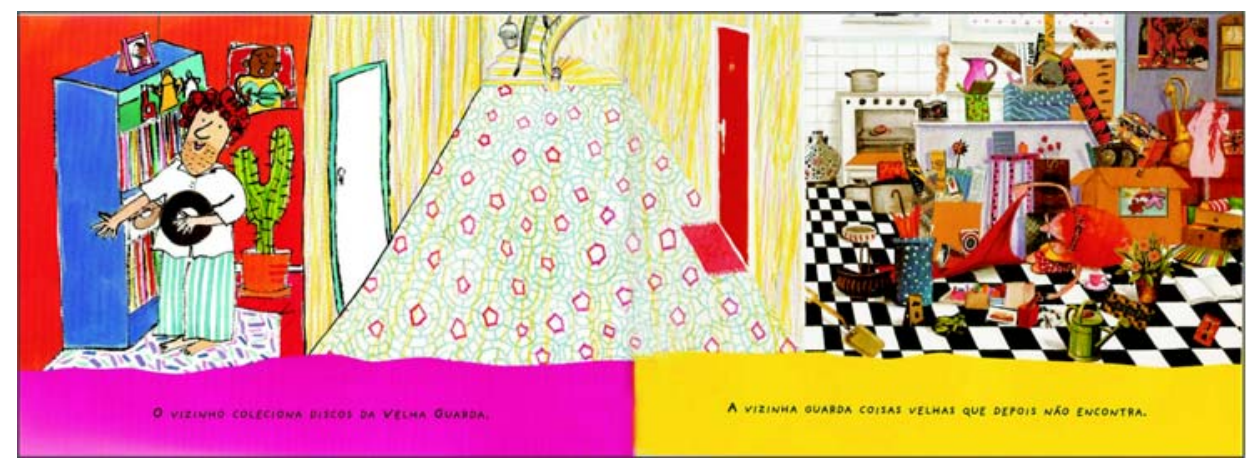

FIGURA 1 - Vizinho, Vizinha

Esse texto é complementado pela roupa do rapaz, suas calças largas e listradas, blusa folgada, descalço, ele cantando emoldurado por um cacto e uma pintura na parede de um músico violonista - o cenário mais perfeito para estar 
com os pés em um tapete rústico e a voz solta na garganta. A simplicidade do rapaz opõe-se à extravagância da mulher do apartamento em frente, que está em busca das coisas perdidas dentro de casa e nunca achadas, uma parafernália: "A vizinha guarda coisas velhas que depois não encontra".

Outro exemplo é a página em que os protagonistas saem e as crianças ficam em casa. O texto diz o horário e o que tio, avó e crianças foram fazer: "Quatro e quarenta: o vizinho saiu com o canário. A sobrinha espreita." (à esquerda); "Vinte para as cinco: a vizinha levou o relógio ao conserto. $\mathrm{O}$ neto observa." (à direita) (FIG.2). Porém, as imagens acrescentam outras informações fundamentais para a compreensão da história: onde e como a sobrinha espreitava, onde e como o neto observava, as portas abertas e o corredor como elo entre as crianças.

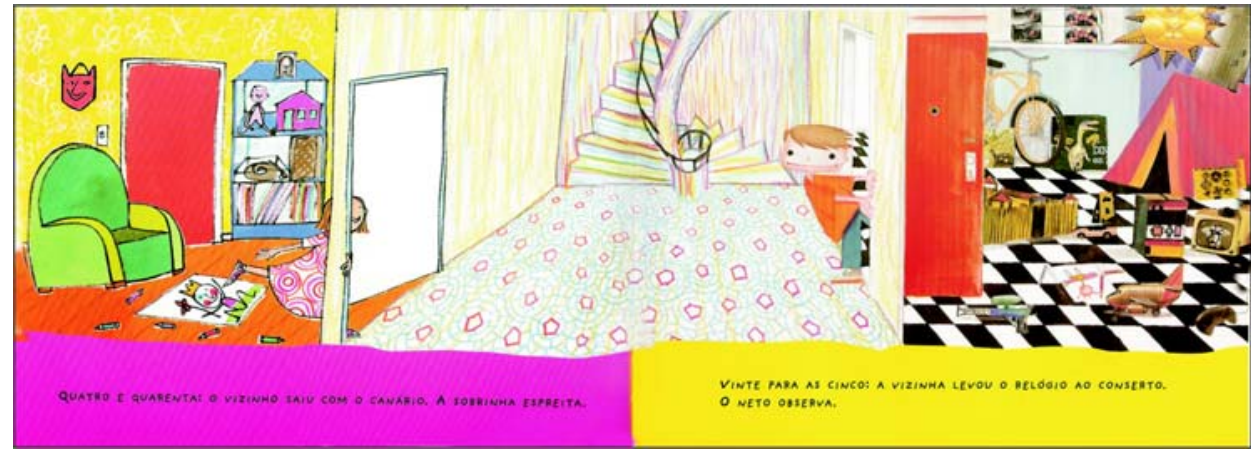

FIGURA 2 - Vizinho, Vizinha

Outros elementos que orientam a leitura são as cores e o estilo de desenho de cada personagem: rosa fúcsia para a página do homem, amarelo ouro para a página da mulher; cada personagem foi desenhada por um artista, explicitando, no estilo do traço e nos objetos de decoração, as marcas da singularidade de cada casa. O conjunto gráfico-editorial é bem-sucedido, sugerindo uma linguagem aberta e convidativa. $\mathrm{O}$ traço, o desenho, a técnica, a mistura de técnicas - como a colagem -, as cores das páginas, os elementos selecionados, tudo constitui o campo de significações das personagens. Embora os conteúdos semânticos estejam imersos tanto nas palavras quanto nas imagens, o elo significativo da existência de cada personagem está no intercâmbio dessas duas dimensões.

Nesse livro, é por meio do conjunto descritivo que se apreende um estilo de vida. Em análise sobre o conceito de estilo bakhtiniano, Fiorin (2006, p. 46-51) lembra que o estilo não traduz a expressão da subjetividade, mas 
resulta de uma visão de mundo, e que estrutura e unifica os enunciados produzidos pelo enunciador. Além disso, o estilo constitui-se em oposição a outros estilos, sendo, portanto, dialógico. Tanto pela objetividade com que se descrevem verbalmente as personagens, como pela suposta dependência da imagem ao referente, a aparente transparência das imagens e das palavras esconde uma opacidade orgânica que busca incessantemente o dito e o não dito, o implícito e o implicável, o intraduzível, mas compreensível pelas fendas de leitura. Por isso, o tempo verbal é o presente do cotidiano, que se desdobra indefinidamente nos mesmos atos diários: passeia com o passarinho às quatro e quarenta, leva o relógio para consertar às vinte para as cinco, ou alimenta um rinoceronte debaixo da pia - formas verbais que dão a dimensão do estar no mundo de cada vizinho. O presente, que do ponto de vista filosófico é a ausência de tempo, marca as histórias pessoais, contrastando o modo de ser de cada um; além disso, não promove a transformação dos sujeitos, apenas fá-los se movimentarem. Esse recurso linguístico aponta na direção da realização de tarefas que enclausuram as personagens no seu mundo interior, como círculos que se repetem. Por isso, o texto se assemelha à estrutura de um roteiro cinematográfico, cada enquadramento à espera de se tornar real através do acontecimento.

Pergunta-se,então, se há um estilo nessa obra, que o poeta norteamericano Bukowski tanto preza, ao dizer que "tudo é uma questão de estilo", e que Bakhtin aponta como marca da subjetividade autoral, indício da enunciação. Ora, é o estilo dessa obra que determina sua leitura, sua agilidade na montagem das personagens e a tensão na constituição plástica do jogo de sentidos. São três ilustradores que imprimem a sua marca no modo de ser de cada personagem, construindo seus mundos particulares (o vizinho, a vizinha e o faxineiro). O confronto das imagens propicia uma leitura em contraponto, cujos níveis mais elevados superam a simples constatação do visto. Esse é um motivo para se trabalhar em página dupla, sempre com uma visão do conjunto. Além da seleção dos objetos que organizam os cenários de cada apartamento, sua composição orienta o espectador para o modo como devem ser compreendidos; ademais, o traço dos desenhos define a natureza de cada um (FIG. 3). Como lembra Mário de Andrade, o traço, essa convenção eminentemente desenhística, denuncia que a escolha do desenho, sua precisão, seus meneios e formas sugestivas é o estilo do artista e, acrescento, orienta o modo de olhar. O conjunto personagem / casa nos é dado a ver por traços inteiramente distintos: a pressão da mão, que carrega o lápis e suas imprecisões, vai modelando rapaz, porta de casa, máscara na parede, poltrona, peixe e até 
passarinho que leva para passear. Ao contrário, a definição da pintura dos objetos do apartamento da vizinha aponta para outra concepção de vida, uma energia diferente, que muitas vezes é sentida pelo leitor / espectador sem que tome consciência dessas marcas / índices que modelam o perfil das protagonistas.

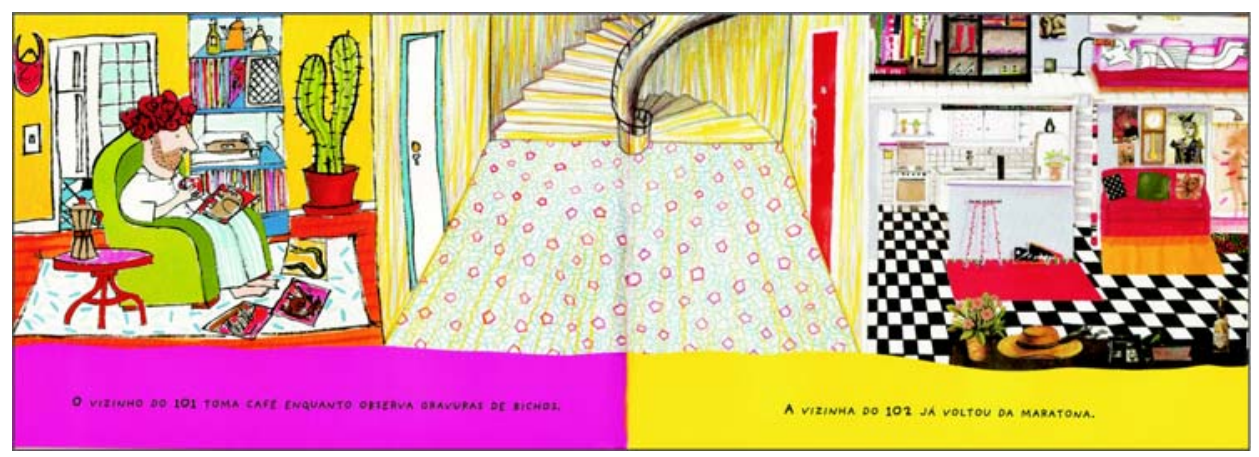

FIGURA 3 - Vizinho, Vizinha

Paradoxalmente, o acúmulo do descritivo se transforma em narrativo. O tempo e o modo como o cotidiano dessas vidas constitui uma narração tornam-se visíveis pela concepção gráfica da autoria. A paginação dupla é, na verdade, dividida em três partes, pois o que está no centro, o corredor, é que determina o fluir do tempo cotidiano, marcado pelas açôes de uma personagem, o faxineiro do prédio, que limpa, lava, descansa, ouve a música vinda do apartamento da vizinha e avança para outros andares. $\mathrm{O}$ corredor (FIG. 4), como lugar de interações e de marcação temporal dos acontecimentos da história, constitui o espaço dinâmico dos encontros, das trocas e das expectativas de transformação.

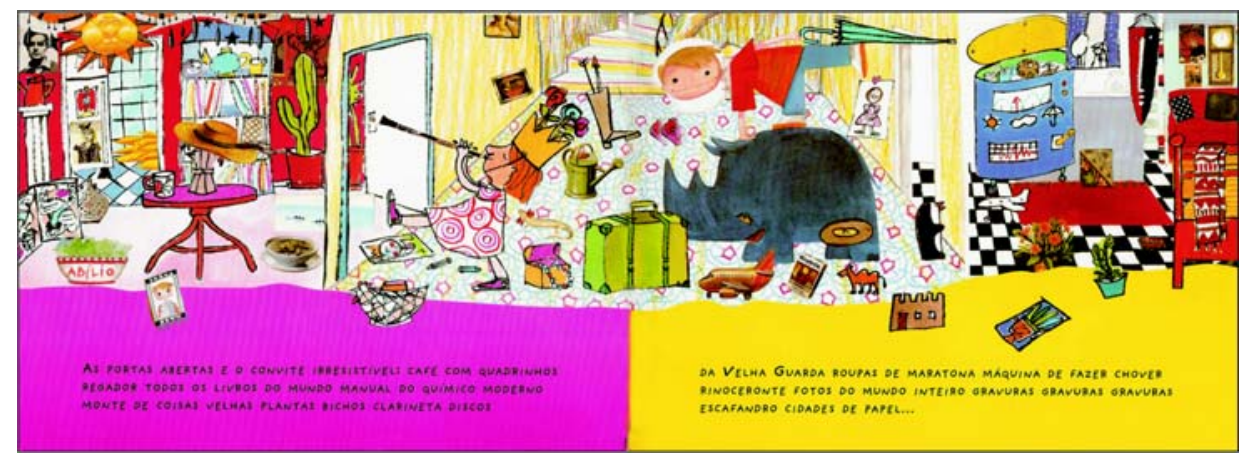

FIGURA 4 - Vizinho, Vizinha 
Quando as crianças se encontram no corredor, as portas abertas permitem o fluxo de vivências e de intercâmbios, com leveza e vivacidade já esquecidas pelos mais velhos. A simplicidade com que esses pequenos atores criam turbulência na vida dos adultos alerta-os para a existência do outro, uma motivação para abrir seus olhos e suas vidas. O texto verbal acompanha as rupturas impostas na organização das casas e nos modelos já constituídos, num acúmulo de palavras sem pontuação, sem verbos, que denunciam a construção de um espaço novo, comum a todos, uma página onde apartamento da esquerda, corredor, apartamento da direita se transformam em um único ambiente renovado de convivência. Ali no corredor está o tempo das mudanças, a expansão das relações, onde o fluxo dos acontecimentos não permite a permanência naquele lugar. Por isso, observa-se a troca permanente de tapete da porta da mulher (FIG.5). A mudança da cor e de padrão vai resultar, ao fim e ao cabo, como lugar da palavra, do aceno, como que pondo em uso a possibilidade de proporcionar interações por meio das quais os homens se constituem: "bem-vindo". O efeito de presença que naturalmente caracteriza a descrição é tratado plasticamente, de maneira que, com a fragmentação da narrativa clássica, constitua a proposta narrativa do livro.

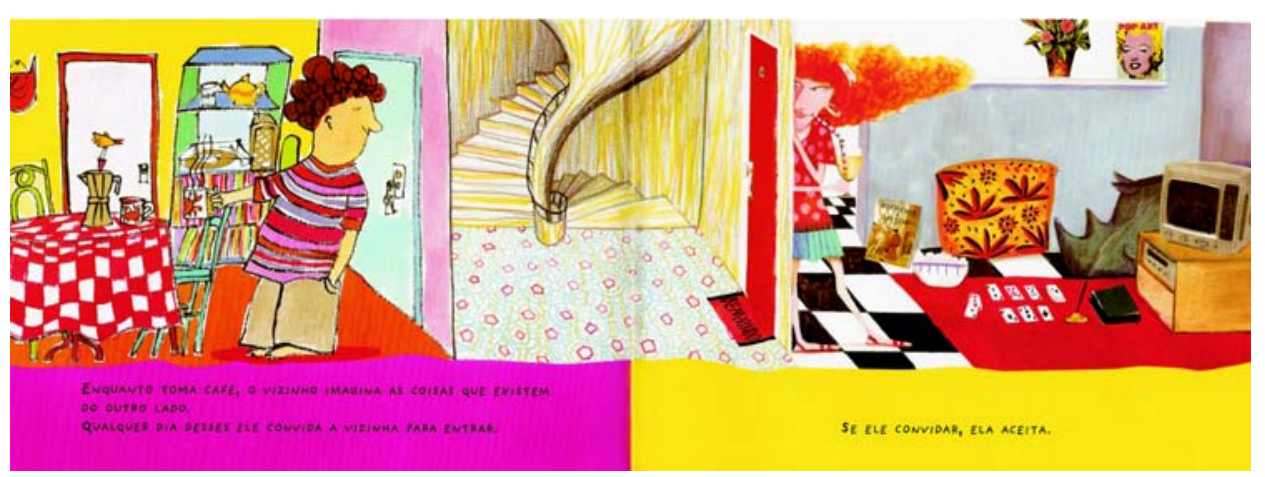

FIGURA 5 - Vizinho, Vizinha

O fato de essa obra realizar, com imagens e palavras, um acúmulo de descrições, possibilita construir outra zona de sentidos, longe do modo de realização do signo linguístico saussureano, em que muitas vezes a relação biunívoca significante / significado marca a posição das imagens como ilustração da palavra ou do texto, o que tende a reafirmar a supremacia de uma linguagem sobre a outra. $O$ projeto narrativo desse livro aproveita a plasticidade das imagens e a discursividade do texto e, finalmente, mescla os dois para apresentar um resultado ético que dialoga com a sua riqueza estética. 


\section{O aspecto da leveza}

O texto de Manoel de Barros é uma narrativa poética, ou uma poesia narrativa, tâo ao gosto da mestiçagem de gêneros, estilos e linguagens que caracteriza a produção literária contemporânea. As fronteiras, em Manoel de Barros, se tornam impuras e avessas, o que faz da sua aparente simplicidade uma arma contra o lugar-comum. O livro Poeminha em língua de brincar se organiza com poucos elementos, sem muitos adereços paratextuais, mas com imagens que fazem uma releitura do texto de Barros, mostrando que caminham juntos, texto e imagem, com a mesma finalidade, como diz ele, de "chegar ao grau de brinquedo para ser séria de rir" (FIG. 6).

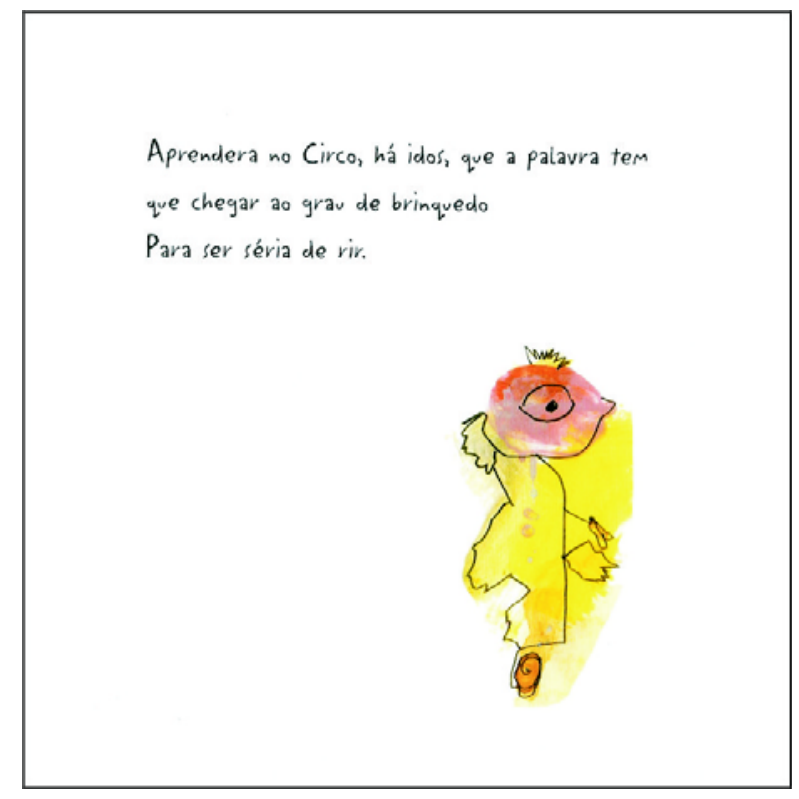

FIGURA 6 - Poeminha em língua de brincar

O projeto editorial trabalha com o intuito da essencialidade, o que permite um enxugamento de elementos visuais e uma concentração no texto verbal. Esse, sim, é o resultado de uma leveza que faz os sentidos acordar. Calvino (1990, p. 28) lembra uma passagem de Paul Valéry, para quem é necessário ser leve como um pássaro, não como a pluma; por isso, acredita que a leveza "está associada à precisão e à determinação, nunca ao que é vago ou aleatório". Manoel de Barros também lembra que sua protagonista "falava em língua de ave e de criança”. Nada mais leve e essencial. Calvino destaca sua 
preocupação em não se acomodar, pelas vicissitudes do viver, e busca deslocamentos constantes para fora do círculo fechado da conservação, que é uma forma de opressão. Descartando a fuga para o sonho ou para a irracionalidade, acrescenta (p. 19):

Quero dizer que preciso mudar de ponto de observação, que preciso considerar o mundo sob uma outra ótica, outra lógica, outros meios de conhecimento e controle. As imagens de leveza que busco não devem, em contato com a realidade presente e futura, dissolver-se como sonhos...

E apresenta três acepções distintas da leveza:

1) um despojamento da linguagem por meio do qual os significados são canalizados por um tecido verbal quase imponderável até assumirem essa mesma rarefeita consistência; 2) a narração de um raciocínio ou de um processo psicológico no qual interferem elementos sutis e imperceptíveis, ou qualquer descrição que comporte um alto grau de abstração; 3) uma imagem figurativa da leveza que assuma um valor emblemático...

Esses sentidos são corporificados no texto de Barros de forma definitiva, obrigando a que sua leitura compreenda "essa mesma rarefeita consistência". A elaboração de sua linguagem dá consistência discursiva ao seu texto, com o frescor de deslocamentos inesperados para alimentar a existência de suas personagens e de seus leitores: "E jogava pedrinhas: Disse que ainda hoje vira a nossa Tarde sentada sobre uma lata ao modo que um bentevi sentado na telha". Essa outra ótica, que dispensa pensar, permite sentir, extravasar o encantamento das palavras livres, que o pensamento solto em forma de pipa, com a linha presa ao coração, faz-de-conta que é verdade. São imagens do texto poético que orientam o entendimento o mundo. Por isso é possível compreender, nessa outra ótica (FIG.7), "que certa rã saltara sobre uma frase dele e que a frase nem arriou. Decerto não arriou porque não tinha nenhuma palavra podre nela". 


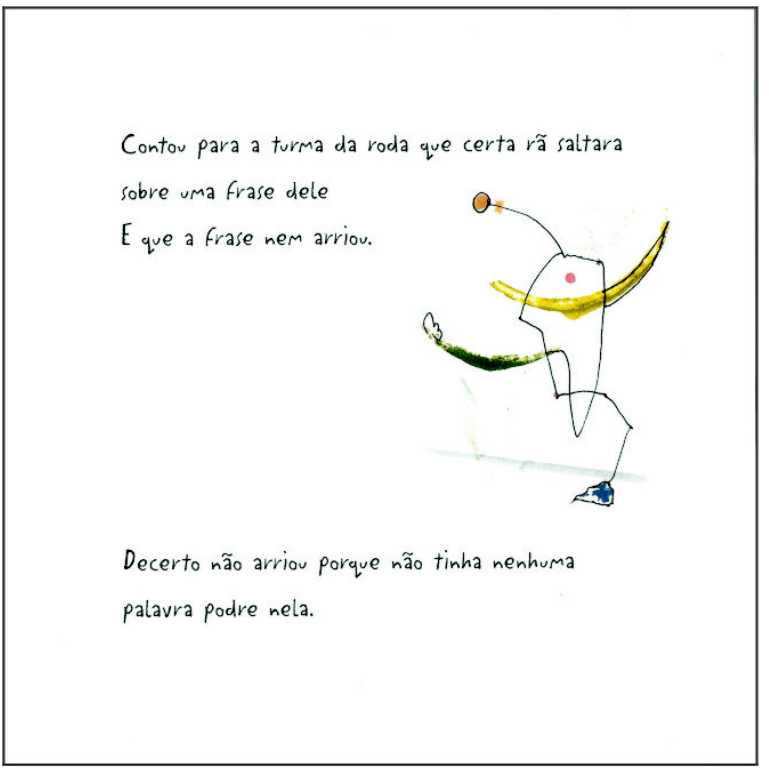

FIGURA 7 - Poeminha em língua de brincar

São imagens colocadas na dimensão do legível, e numa outra dimensão do inteligível, pois não basta a imagem no texto, afeita à noção de descrição pictural. Nesse caso de Barros, as imagens verbais caracterizam um mundo que deve ser ainda construído, são imagens inaugurais, fluidas e abertas para a interpretação do leitor. Para compor a terceira acepção da leveza, "uma imagem figurativa da leveza que assuma um valor emblemático", o autor preocupa-se em dar, na apresentação, logo no início do texto, o tom da sua personagem, o menino: "ele tinha no rosto um sonho de ave extraviada", e que se repetirá no meio da história, enfatizando que sua expressão poética é a maneira com a qual se arremessará para o mundo dos sentidos.

Barros fala das coisas da natureza como as coisas de um mundo mais palpável, mas nada nele é palpável, o que resulta em uma concretude sem peso. Calvino, ao falar de Lucrécio, o recoloca como o poeta em que o conhecimento do mundo se transforma em dissolução da compacidade do mundo, na percepção do que é infinitamente minúsculo, móvel e leve. Diz ele (1990, p. 21): "A poesia do invisível, a poesia das infinitas potencialidades imprevisíveis, assim como a poesia do nada, nascem de um poeta que não nutre qualquer dúvida quanto ao caráter físico do mundo". Esse é o paradoxo que Barros quer nos ofertar. 
A natureza da obra de Manoel de Barros é um labirinto em direção ao Nada, ao enfrentamento que elimina a Dona Lógica da Razão, para ir em direção à compreensão das coisas na sua inteireza, na sua natureza irrestrita. No caso desse livro de Barros, o questionamento do autor sobre a lógica da racionalidade supõe embate com a perspectiva de sintese pacífica, portanto, uma crença na fratura irredutível da lógica que sustenta o discurso. Isso é o que possibilita a existência daquelas imagens visuais do livro: pois o texto de Barros, mantendo a opacidade enunciativa de seu discurso poético, sustenta a tensão criadora com outros sistemas, dando margem à autonomia das imagens em relação ao texto fonte. Por outro lado, a posição autônoma do artista permite a realização de um intercâmbio com o texto literário fora do parâmetro linguajeiro, operando no âmbito da plasticidade. Esse é o meio pelo qual imagem e texto se assentam na natureza leve de suas dimensões discursiva e plástica. O que os aproxima, portanto, é a possibilidade de a imagem falar a partir do texto, havendo espaço para que cada dimensão melhor se aproprie de suas modalidades expressivas. Mantendo a opacidade significativa como característica comum entre o literário e o plástico, esses registros não funcionam como espelho, assemelhando-se um ao outro. Do ponto de vista da sua realização, as imagens, que aqui são desenhos pintados, não intentam explicar nem descrever coisa alguma, não se interessam em fazer o leitor compreender, mas incentivam uma postura frente ao ato criador. Essa ritualização contemporânea da imagem que dá autoridade à realização autoral se aproxima da linguagem poética bakhtiniana (1998), que vê na autoridade poética o traço de encantamento cuja força significa o homem que fala sua palavra.

Manoel de Barros não se preocupa só em ser entendido, mas em fazer de seus versos uma "coisa-nada", uma língua a ser criada, para brincar, como um evento próprio da poesia, um monólogo no sentido bakhtiniano. Sentencia: "Se o Nada desaparecer a poesia acaba" (FIG. 8). 


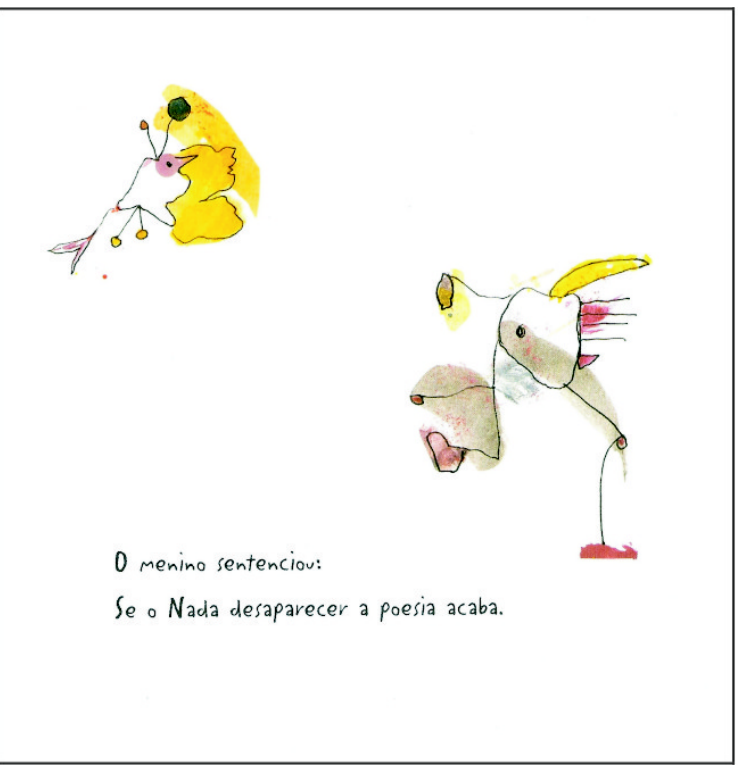

FIGURA 8 - Poeminha em lingua de brincar

Nesse sentido, o discurso poético se ausenta do cotidiano e constitui um monólogo, no sentido bakhtiniano, uma construção, quase um objeto conceitual. Essa é a forma de, transgredindo a fala prosaica, submetê-la à sua própria essencialidade. Sua proposta é desfazer os lugares-comuns, deixar que as experiências verbal e visual sejam o resultado de uma disponibilidade para o sensível.

O texto começa pelo pronome pessoal "ele": "Ele tinha no rosto um sonho de ave extraviada. Falava em língua de ave e de criança". Como se houvesse um contrato de antemão com o leitor, Barros constitui, no texto, o espaço de diálogo com o leitor; afinal, "dispensava pensar". A consideração de que aí está implícita a estrutura clássica do gênero conto, que se consagrou infantil, possibilita subentender o Era uma vez um menino. Já no começo, pois, o autor denuncia o tom que o faz original, distanciado do repetido. Mesmo mantendo a estrutura canônica do conto, a sua linguagem poética transgride as normas clássicas da narratividade e seu texto começa a desconcertar um leitor distraído, mais afeito a uma leitura mecânica. Esse mundo particular da linguagem, em que o Nada é língua de brincar, é a própria casa do jabuti, a poesia, onde o menino se interna e ali se salva: "E se internou na própria casca ao jeito que o jabuti se interna". E sendo o Nada língua de brincar, o é também na plasticidade oferecida ao leitor: o desenho, altamente conceitual, traduz em 
seus traços, como que tocando levemente a lembrança de um figurativismo, a manifestação de um Nada significativo.

Por outro lado, tomando um novo ponto de vista a respeito do projeto discursivo da obra, as imagens assumem uma funcionalidade, mostrando plena interação com a proposta: a técnica e o material dos desenhos, menos que reproduzir um modo infantilizado de expressão, desejam cultivar um olhar que traduza a liberdade infantil da expressão e do livre compreender. Vale a pena notar a única vez em que a ilustração interrompe o fluxo narrativo e abre espaço para o destaque da enunciação: o comentário do narrador quer justificar e dar coerência à existência do seu personagem - "Decerto não arriou porque não tinha nenhuma palavra podre nela".

Do ponto de vista da construção dessas duas instâncias - verbal e plástica-, portanto, é o vazio preenchido pelo Nada que tudo significa. Texto e imagem caminham juntos brincando com os sentidos, com as percepçôes, nos convocando ao estado de criação. Esse livro se abre para acolher a arte, a estética, em que o Nada é o todo.

\section{A interdiscursividade}

Esse conceito bakhtiniano tem sua origem no cruzamento de enunciados que, por sua própria natureza, são atravessados por diferentes vozes. Em texto sobre as ideias de Bakhtin, Fiorin (2006, p. 51-55) apresenta o nascimento do termo intertextualidade, suas apropriaçōes e equívocos. Por isso, a preferência pelo termo interdiscursividade, que dá condições de melhor compreender a discussão que pretendo travar. Entendendo a materialidade do enunciado como texto e o enunciado como uma posição assumida pelo enunciador, observa-se que o enunciado é da ordem dos sentidos e que o texto é manifestação do enunciado. Além disso, Fiorin alerta que "o enunciado não é manifestado apenas verbalmente, o que significa que, para Bakhtin, o texto não é exclusivamente verbal, pois é qualquer conjunto coerente de signos, seja qual for sua forma de expressão (pictórica, gestual etc.)". Dessa forma, o que proponho, no momento, é compreender as relações entre o discurso imagético e o discurso verbal como possibilidades interpretativas, numa das obras de Reina Rennó.

Coração de ganso é um livro cuja temática se desenvolve com dois grupos de personagens: de um lado, gansos, de outro, galinha e seus pintinhos. A história se desenvolve quando um dos gansos se encanta pela galinha e seus pintinhos e resolve se juntar ao grupo. Seus companheiros rechaçam qualquer 
possibilidade de aproximação e aprisionam seu parceiro como castigo. Galinha e pintinhos o salvam e o ganso resolve ir embora com os amigos, abandonando seus pares. Sua realização gráfica apresenta poucos elementos, com formato de folha quadrado e toda a história é colorida a lápis de cor. Os elementos são bem definidos, organizando uma estrutura narrativa canônica. $\mathrm{O}$ jogo de leitura que está presente na obra é proposto pela relação de intertextualidade com a história clássica infantil do patinho feio (FIG. 9).

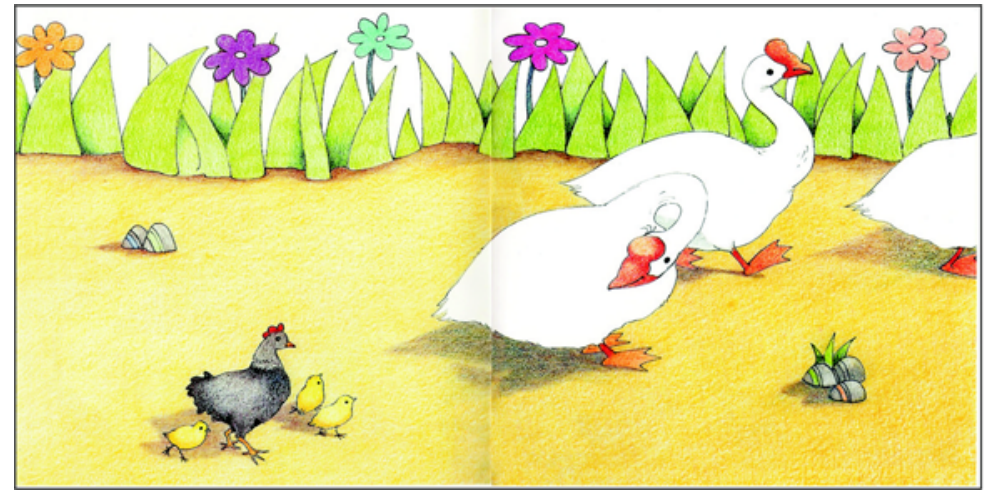

FIGURA 9- Coração de Ganso, página dupla

No movimento contrário, a protagonista não busca a semelhança como fator de segurança e identificação para constituição da subjetividade, mas a liberdade da escolha pelo amor favorece a convivência com a diferença. É uma temática contemporânea, arrojada para a idade do leitor-modelo em questão e para a época em que vivemos. O surgimento de obras em que o protagonismo é transferido para personagens em cuja construção o bem e o mal lhes são inerentes e do mesmo peso têm se avolumado - a exemplo de Chapeuzinho Vermelho, Bela Adormecida, entre outros, em que os valores positivos e negativos já não são tão opostos, o que evita uma ótica maniqueísta. Mas é o fundo ético, o qual ampara o enredo, que dá sustentação à concepção do projeto editorial. As relações interdiscursivas de construção da narrativa encontram-se em vários livros infantis contemporâneos, dialogando com algumas formas renovadas de sociabilidade, provando que é possível mostrá-las na ficção (FIG.10). O gênero conto continua a ser explorado na literatura infantil; no entanto, os conteúdos semânticos dialogam com as questôes do presente, alterando as maneiras com que os leitores mirins se defrontam com as questóes éticas. 


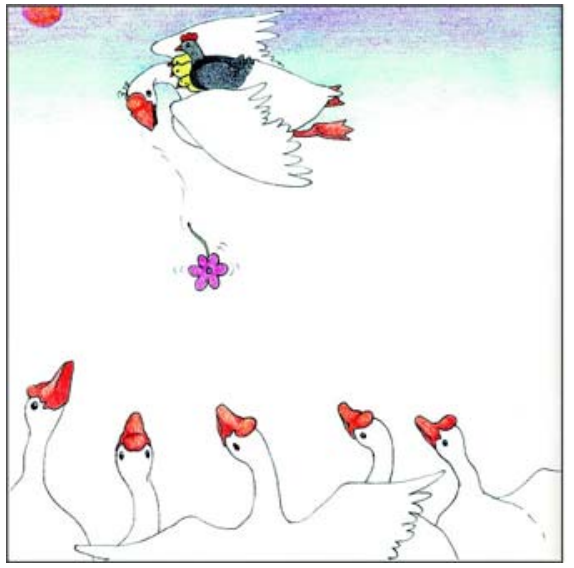

FIGURA 10 - Coração de Ganso

\section{Conclusão}

As abordagens aqui propostas apontam alguns aspectos de análise e possibilidades de interpretação das relações entre imagens e textos verbais em livros de literatura infantil, com a finalidade de reconhecer diferentes linguagens que atuam na estruturação de gêneros. Frequentemente professores tendem a fazer uma leitura da obra apoiada na linearidade do sistema de escrita alfabético: em primeiro lugar, leem o texto verbal para as crianças e, em seguida, apresentam a página lida com as imagens que se restringem, dessa forma, à mera ilustração do que foi ouvido. A interrupção da história, para que se vejam as "ilustraçôes", tende a suspender o fluxo narrativo, com a intenção de introduzir uma instância contemplativa. Ainda que essa estratégia aproxime o leitor da leitura, a fragilidade desse expediente situa-se justamente na criação de uma dificuldade inicial para a simultaneidade de leitura verbal e visual, o que, em várias obras, é o que propicia a produção de sentidos.

Outra consideração relevante é a de que os projetos gráfico-editoriais das obras de literatura infantil não devem ser compreendidos somente do ponto de vista técnico, abordados principalmente pela área de design gráfico. Mesmo aí, há estudos que sinalizam a importância do design como linguagem, na construção visual do suporte e na atualização do gênero. Ilustradores que são autores e autores ilustradores, cada vez mais, propõem uma dinâmica de interação entre imagem e texto verbal que, com frequência, resultam na hibridização de linguagens. O gênero conto se apropria de referenciais cuja plasticidade amplia e renova suas características discursivas. 
Portanto, algumas questões estão no centro das discussões sobre a formação da competência leitora do professor. Primeiramente, a formação inicial de professores nas universidades deve tratar a leitura literária de forma mais inclusiva, contemporânea para que se recuperem as tensões que as linguagens verbais e visuais propõem. A leitura literária de obras infantis deve ser considerada como objeto de ensino e pesquisa em contextos de formação acadêmica em cursos de Pedagogia e Letras, com um espaço mais definido, assentado num ambiente de formação cultural que ajude o futuro professor a se desenvolver intelectualmente e a se posicionar de maneira multidisciplinar. Em segundo lugar, os cursos de formação em serviço - ou formação continuada - devem auxiliar o professor que não teve oportunidade de tratar do assunto com informaçôes e vivências nessa área para que possa empreender um trajeto de construção de conhecimento que inclua autonomia e uma perspectiva mais contemporânea. Afinal, as crianças e os jovens de hoje estão a nos convocar novos olhares sobre nossa capacidade de ler o mundo.

\section{Referências bibliográficas}

ANDRADE, Mário de. Do Desenho. In: Aspectos das Artes Plásticas no Brasil. São Paulo: Martins, 1965. p. 69-77.

BAKHTIN, Mikhail. Estética da criação verbal. Tradução do russo de Paulo Bezerra. São Paulo: Martins Fontes, 2003.

BAKHTIN, Mikhail. O discurso na poesia e o discurso no romance. In: Questōes de literatura e estética: a teoria do romance. São Paulo: Ed. Unesp, 1998. 439 p.

BARROS, Manoel de. Poeminha em lingua de brincar. Ilustrações: Martha de Barros. São Paulo: Record, 2007.

BELMIRO, Celia Abicalil. Um estudo sobre relaçôes entre imagens e textos verbais em cartilhas de alfabetização e livros de literatura infantil. Tese (Doutorado em Educação) - Universidade Federal Fluminense, 2008.

BELMIRO, Celia Abicalil. Textos literários e imagens, nas mediações escolares. In: PAULINO, Graça; COSSON, Rildo (Org.). Leitura literária: a mediação escolar. Belo Horizonte: Faculdade de Letras da UFMG, 2004. p.147-153.

BELMIRO, Celia Abicalil; AFONSO Jr., Delfim; BARROS, Armando M. Imagens e práticas intertextuais em processos educativos. In: PAIVA, Aparecida; MARTINS, Aracy; PAULINO, Graça; VERSIANI, Zélia. Literatura e Letramento: espaços, suportes, interfaces. Belo Horizonte: Autêntica, 2003. p. 209-224. 
BELMIRO, Célia Abicalil. A Imagem e suas formas de visualidade nos livros didáticos de Português. Educação e Sociedade. Campinas (SP): Cedes, Ano XXI, n. 72, p. 11-31, ago. 2000.

CALVINO, Ítalo. Leveza. In: Seis propostas para o próximo milênio. Trad. Ivo Barroso. São Paulo: Cia. das Letras, 1990. p. 13-41.

FIORIN, José Luiz. O estilo. In: Introdução ao pensamento de Bakhtin. São Paulo: Ática, 2006. 144p.

MELLO, Roger. Vizinho, vizinha. Ilustrações: Graça Lima, Mariana Massarani, Roger Melo. São Paulo: Cia. das Letrinhas, 2007.

PAULINO, Graça; COSSON, Rildo (Org.). Leitura literária: a mediação escolar. Belo Horizonte: Faculdade de Letras da UFMG, 2004.

RENNÓ, Regina. Coração de ganso. São Paulo: Editora Mercuryo, 2007. Coleção Mercuryo Jovem.

Recebido em setembro de 2009. Aprovado em outubro de 2009. 